\title{
HIDROLISIS POLISAKARIDA XILAN JERAMI MENGGUNAKAN LARUTAN ASAM KUAT UNTUK BAHAN DASAR PRODUKSI BIOETANOL
}

\author{
Gading Wilda Aniriani $^{\left({ }^{*}\right)}$, Nurul Fitria Apriliani ${ }^{2)}$, Eko Sulistiono ${ }^{3)}$ \\ ${ }^{1,3)}$ Program Studi Kesehatan Lingkungan, Fakultas Teknik, Universitas Islam Lamongan \\ ${ }^{2}$ Program Studi Teknik Informatika, Fakultas Teknik, Universitas Islam Lamongan \\ *Corresponding author : gading.wildaa@gmail.com
}

\begin{abstract}
ABSTRAK
Hidrolisis merupakan proses pemecahan polisakarida (gula kompleks) menjadi polimer yang lebih sederhana, mengingat syarat utama dari proses fermentasi untuk produksi bioetanol adalah gula monomer atau dimer. Polisakarida yang digunakan yakni hasil pretreatment dan ekstraksi jerami. Penggunaan cara kimiawi pada proses hidrolisis ini bertujuan untuk mendapatkan hasil yang optimum dengan waktu yang singkat. Metode penelitian yang digunakan adalah hidrolisis asam dengan membandingkan dua jenis larutan asam kuat yaitu asam sulfat $\left(\mathrm{H}_{2} \mathrm{SO}_{4}\right)$ dan asam klorida $(\mathrm{HCl})$ dengan konsentrasi masig-masing sebesar $0.5 \mathrm{~N}$. Hidrolisis dilakukan dalam kondisi pada suhu $115{ }^{\circ} \mathrm{C}$ selama 60 menit pada tekanan $1 \mathrm{~atm}$. Gula sederhana yang dihasilkan telah diuji dengan uji gula total, dengan hasil bahwa gula pereduksi diketahui dari selisih gula total pada kontrol tanpa perlakuan. Uji gula total dilakukan menggunakan metode Dubois, pengujian ini dilakukan pada hasil optimum dari hidrolisis yaitu asam klorida $(\mathrm{HCl})$. Sampel yang diujikan yaitu, xilan (XI) dan kontrol (-) xilan (k-x). Analisis gula total menghasilkan sebanyak 2.906 $\mathrm{mg} / \mathrm{L}$ untuk XI, sebanyak $728 \mathrm{mg} / \mathrm{L}$ untuk (k-x) dengan hasil bahwa perolehan gula pereduksi sebesar $2.124 \mathrm{mg} / \mathrm{L}$. Selisih hasil gula total yang diperoleh antara perlakuan dan kontrol mengindikasikan bahwa proses hidrolisis berhasil mendapatkan gula pereduksi.
\end{abstract}

Kata kunci: gula kompleks, hidrolisis asam, gula sederhana, gula pereduksi dan gula total.

\section{HYDROLYSIS OF POLYCOXARIDA XYLANE STRAW USING STRONG ACID ACID SOLUTION FOR BASIC MATERIALS OF BIOETANOL PRODUCTION}

\begin{abstract}
Hydrolysis is the process of breaking polysaccharides (sugar complexes) into simpler polymers, considering the main requirements of the fermentation process for bioethanol production are monomeric or dimeric sugars. The polysaccharides used are the results of pretreatment and extraction of straw. The use of chemical methods in the hydrolysis process aims to obtain optimum results with a short time. The research method used is acid hydrolysis by comparing two types of strong acid solutions namely sulfuric acid $(\mathrm{H} 2 \mathrm{SO} 4)$ and hydrochloric acid $(\mathrm{HCl})$ with a concentration of each of $0.5 \mathrm{~N}$. Hydrolysis is carried out under conditions at a temperature of 115 $0 \mathrm{C}$ for 60 minutes at a pressure of $1 \mathrm{~atm}$. The simple sugar produced was tested with a total sugar test, the result of the reducing sugar was known from the total sugar difference in the control without treatment. The total sugar test was carried out using the Dubois method, this test was carried out on the optimum results of hydrolysis, namely hydrochloric acid $(\mathrm{HCl})$. The sample tested were, xylan (XI) and control (-) xylan (k-x). Analysis of total sugar yielded as much as $2,906 \mathrm{mg} / \mathrm{L}$ for XI, as much as $728 \mathrm{mg} / \mathrm{L}$ for $(\mathrm{k}-\mathrm{x})$ the result of the acquisition of reducing sugars was 2,124 $\mathrm{mg} / \mathrm{L}$. The difference of the result total sugar produced between treatment and control indicates that the hydrolysis process succeeded in obtaining reducing sugars.
\end{abstract}

Keywords: complex sugar, acid hydrolysis, simple sugar, reducing sugar and total sugar.

\section{PENDAHULUAN}

Hidrolisis asam kuat menghasilkan gula yang tinggi $(90 \%$ dari hasil teoritik) dibandingkan dengan hidrolisis asam encer. Kecepatan hidrolisis oleh asam pada konsentrasi tinggi tidak tergantung pada struktur kristal selulosa, sehingga lebih dari 
90\% glukosa dapat dihasilkan. Kelemahan dari hidrolisis asam encer adalah degradasi gula hasil di dalam reaksi hidrolisis dan pembentukan produk samping yang tidak diinginkan. Degradasi gula dan produk samping ini tidak hanya akan mengurangi hasil panen gula, tetapi produk samping juga dapat menghambat pembentukan etanol pada tahap fermentasi selanjutnya (Taherzadeh dan Karimi, 2007). Hidrolisis dilakukan dengan menggunakan asam pekat akan mempercepat proses hidrolisis tetapi akan menurunkan hasil hidrolisis karena glukosa mudah sekali diuraikan. Berdasarkan penelitian Taherzadeh dan Karimi (2007), proses hidrolisis dipengaruhi oleh ukuran partikel, rasio asam dengan substrat, jenis dan konsentrasi asam, suhu dan waktu hidolisis. Peningkatan konsentrasi asam yang digunakan akan menurunkan jumlah glukosa yang dihasilkan karena glukosa yang terbentuk akan terdegradasi lebih lanjut. Hasil degradasi glukosa yang dapat mengganggu dan merusak hasil hidrolisis diantaranya HMF (hidroksi metil furfural). Oleh karena itu dalam penelitian ini akan menggunakan hidrolisis asam pekat dengan variasi konsentrasi untuk mengetahui hasil gula sederhana yang optimal. Untuk mendapatkan hasil hidrolisis yang ideal maka gula yang dihasilkan harus segera dipisahkan dari medium hidrolisisnya. Pada hidrolisis suhu sedang, proses hidrolisis bisa memberikan hasil yang lebih rendah karena proses dekomposisi. Suhu yang tinggi sering digunakan untuk menghidrolisis selulosa (Sun dan Cheng, 2002).

Proses hidrolisis yang dilakukan dapat menghasilkan gula pereduksi untuk difermentasi menjadi etanol (Sun and Cheng, 2002). Sesuai dengan sifatnya, karbohidrat manapun dapat dihidrolisis dengan asam. Proses hidrolisis terjadi saat struktur kristal selulosa rusak sehingga selulosa terurai menghasilkan serangkaian oligosakarida dan monosakarida termasuk selobiose, selotriose, dan selotetraose (Feller, 1986). Selain itu, hemiselulosa turut terurai menjadi senyawa gula sederhana menjadi glukosa, manosa, xilosa dan arabinosa (Mosier et al., 2005). Hidrolisis yang sempurna dari selulosa akan menghasilkan glukosa, sedangkan hemiselulosa menghasilkan beberapa monomer gula pentose (C5) dan heksosa (C6). Polisakarida yang didapatkan dari proses pretreatment limbah lignoselulosa merupakan hasil dari ekstraksi dalam penelitian sebelumnya.

\section{TINJAUAN PUSTAKA}

\section{Gula sederhana}

Gula sederhana terdiri dari beberapa macam yakni, oligosakarida, disakarida, dan monosakarida. Xilan merupakan heteropolimer yang terdiri atas ikatan $\beta-1,4$ D-xilose dan cabang-cabang arabinose, asam glukuronat dan residu manosa atau asetil. Hidrolisis sempurna dari xilan biasanya membutuhkan peran endo $\beta$-1,4-xilanase, $\beta$ xilosidase, $\mathrm{L}$ arabinofuranosidase, glukuronidase dan asetilxilan esterase (Prakash, et al., 2011).

\section{Hidrolisis asam}

Hidrolisis berasal dari bahasa Greek dari kata hydor yang berarti air dan lisis yang berarti kehilangan. Hidrolisis adalah pemecahan kimiawi suatu molekul karena pengikatan air, menghasilkan molekulmolekul yang lebih kecil. Proses ini dinyatakan dengan persamaan reaksi sebagai berikut :

$$
\mathrm{AB}+\mathrm{H}_{2} \mathrm{O} \rightarrow \mathrm{AOH}+\mathrm{BH}
$$

Proses hidrolisis dapat dilakukan dengan enzim dan asam. Beberapa asam yang umum digunakan untuk hidrolisis asam antara lain adalah asam sulfat $\left(\mathrm{H}_{2} \mathrm{SO}_{4}\right)$, asam perklorat, dan $\mathrm{HCl}$. Asam sulfat merupakan asam yang paling banyak diteliti dan dimanfaatkan untuk hidrolisis asam. Hidrolisis asam dapat dikelompokkan menjadi hidrolisis asam pekat dan hidrolisis asam encer (Taherzadeh dan Karimi, 2007).

\section{Gula Total}

Gula total merupakan campuran gula reduksi dan non reduksi yang merupakan hasil hidrolisa pati. Semua monosakarida dan disakarida kecuali sukrosa berperan sebagai agensia pereduksi dan karenanya dikenal sebagai gula reduksi. Kemampuan senyawa gula mereduksi agensia pereduksi pengoksidasi mendasari pelbagai cara pengujian untuk glukosa dan gula-gula reduksi lainnya (Aniriani, 2014).

\section{METODE PENELITIAN}

Penelitian dilakukan pada bulan April 2018 sampai dengan Desember 2018 di Universitas Islam Lamongan dan di 
Laboratorium PT. Angler Biochemlab. tbk Surabaya.

\section{Preparasi Limbah}

Limbah jerami padi, tongkol jagung dan ampas tebu di keringkan di bawah terik matahari sampai mendapatkan berat kering, dipotong menjadi ukuran kecil kemudian di dihancurkan dengan masing giling. Setelah menjadi serbuk kemudian dilakukan pembubukan lolos saringan 40 mesh, hasil modifikasi dari Lee (2003). Kandungan total selulosa, hemiselulosa dan lignin bagas didapatkan dari analisis proksimat dan analisis serat dalam penelitian sebelumnya (Aniriani, 2017).

\section{Hidrolisis Asam}

Hidrolisis dilakukan dengan dua jenis larutan yakni asam sulfat $\left(\mathrm{H}_{2} \mathrm{SO}_{4}\right)$ dan asam klorida $(\mathrm{HCl})$. Larutan polisakarida dibuat dengan menimbang 0,1 gr xilan/selulosa yang dilarutkan dengan $10 \mathrm{~mL}$ akuades. Kemudian ditambahkan ditambahkan $0.5 \mathrm{~N}$ HCL/ $\mathrm{H}_{2} \mathrm{SO}_{4}$ sebanyak $2.5 \mathrm{~mL}$. Larutan kemudian dihidrolisis pada suhu $115{ }^{0} \mathrm{C}$ selama 1 jam pada tekanan 1 atm. Larutan diangkat, didinginkan dan dinetralisasi dengan $\mathrm{Na}_{2} \mathrm{CO}_{3}$ $10 \%$. Hasil dari hidrolisis kemudian dianalisis kadar gula reduksi dan gula total.

\section{Uji Gula Total}

Pengukuran Kadar Xilan atau Selulosa (Gula Total) dengan Metode PhenolSulphuric Acis (Asam Fenol Sulfat) (Dubois et al., 1956). Hasil pengambilan sampel dari kedua jenis hasil hidrolisis, kemudian disentrufugasi pada $6000 \mathrm{rpm}$ selama 5 menit. Supernatant kemudian diencerkan 100 kali. Kemudian diambil $0.5 \mathrm{~mL}$ dari larutan hasil pengenceran tersebut ke dalam tabung reaksi kecil, setelah itu ditambahkan fenol 5 $\%$ sebanyak $0.5 \mathrm{~mL}$ dan $2.5 \mathrm{~mL}$ larutan $\mathrm{H}_{2} \mathrm{SO}_{4}$ lalu dikocok dengan vortex. Setelah dikocok lalu didiamkan 10 menit dan diletakkan di dalam water bath dengan suhu $40{ }^{0} \mathrm{C}$ selama 20 menit. Kadar glukosa (gula total) dalam sampel dianalisis dengan diukur absorbansinya menggunakan spektrofotometer Vis $490 \mathrm{~nm}$. Sebelumnya dibuat standar glukosa dengan konsentrasi 10, 20, 40, 60, 80, 100, 120, dan 200 ppm.

\section{HASIL DAN PEMBAHASAN}

Proses hidrolisis dilakukan dengan melarutkan serbuk polisakarida dari perolehan yield tertinggi yakni jerami dalam $0.5 \mathrm{~N}$ larutan asam kuat hidrogen peroksida (H2SO4) dan Hidrogen klorit ( $\mathrm{HCl})$. Hal tersebut dilakukan untuk mengetahui kondisi optimum dalam proses hidrolisis. Kelebihan dari proses hidrolisis menggunakan asam ini mempunyai waktu yang cepat dengan hasil yang optimum dibandingkan dengan hidrolisis secara enzimatik yang membutuhkan waktu yang lama dan hasil yang kurang optimum.

Perbandingan hasil yang diperoleh diantara hidrolisis menggunakan asam $\mathrm{H}_{2} \mathrm{SO}_{4}$ dengan $\mathrm{HCl}$ mempunyai hasil optimasi yang berbeda, dengan proses perlakukan yang sama yaitu merendam dalam masing-masing larutan asam selama 60 menit pada suhu 115 ${ }^{0} \mathrm{C}$ dengan tekanan $1 \mathrm{~atm}$. Perbedaan optimasi dapat dilihat pada saat penetralan $\mathrm{pH}$ menggunakan $\mathrm{Na}_{2} \mathrm{CO}_{3} 10 \%$, pada larutan yang terhidrolisis oleh $\mathrm{HCl}$ lebih membutuhkan penambahan $\mathrm{Na}_{2} \mathrm{CO}_{3} \quad 10 \%$ dalam jumlah yang lebih sedikit jika dibandingan larutan yang terhidrolisis oleh $\mathrm{H}_{2} \mathrm{SO}_{4}$. Hal tersebut mengakibatkan, proses penetralan $\mathrm{pH}$ membutuhkan waktu yang lama dan jumlah $\mathrm{Na}_{2} \mathrm{CO}_{3}$ yang banyak. Sehingga dapat disimpulkan bahwa proses hidrolisis yang optimum adalah menggunakan larutan asam $\mathrm{HCl}$, dengan pertimbangan efisiensi waktu dan murah karena membutuhkan bahan penetral dengan jumlah yang sedikit. Indikatrol $\mathrm{pH}$ yang telah netrak ditunjukkan dari perubahan warna menjadi cokelat tua (Gambar 1).

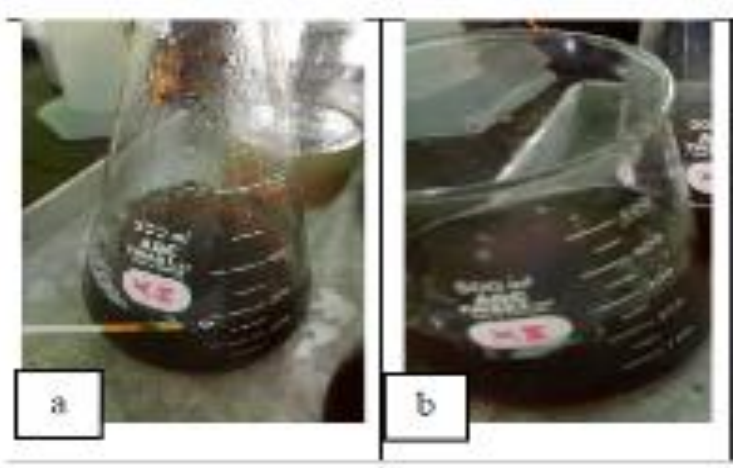

Gambar 1. Hasil penetralan $\mathrm{pH}$ menggunakan $\mathrm{Na}_{2} \mathrm{CO}_{3} 10 \%$. (a) xilan terhidrolisis oleh $0.5 \mathrm{~N}$ $\mathrm{HCl}$, (b) xilan terhidrolisis $0.5 \mathrm{~N} \mathrm{H}_{2} \mathrm{SO}_{4}$, 


\section{Uji Gula Total}

Hasil dari proses hidrolisis paling optimum akan dianalisis gula total menggunakan metode (Gula Total) dengan Metode Phenol-Sulphuric Acid (Asam Fenol Sulfat) (Dubois et al., 1956) yakni perlakuan XI (Xilan $\mathrm{HCl}$ ) dan Kontrol (-) xilan. Standart gula yang digunakan dalam metode ini adalah gula monomer xilosa pada perolehan gula total xilan. Analisis perlakuan kontrol negatif bertujuan agar dapat membandingkan hasilnya dengan perlakukan sehingga dapat dibuat kesimpulan. Perolehan hasil analisis gula total pada perlakuan XI jika dibandingkan dengan kontrol masingmasing mengalami kenaikan total gula $(\mathrm{mg} / \mathrm{L})$. Perolehan gula total pada polisakarida xilan tanpa perlakuan (kontrol ()) yakni sebesar $782 \mathrm{mg} / \mathrm{L}$, dan pada xilan terhidrolisis (XI) sebesar $2906 \mathrm{mg} / \mathrm{L}$ (Tabel 1). Artinya proses hidrolisis berhasil dengan dibuktikannya kenaikan jumlah total gula sebanyak $2124 \mathrm{mg} / \mathrm{L}$. Aniriani, GW. dkk (2014) menyatakan bahwa gula total merupakan campuran gula reduksi dan non reduksi yang merupakan hasil hidrolisa pati. Gula reduksi adalah gula hasil pemecahan polisakarida, sedangankan gula non-reduksi adalah hasil samping dari proses. Semua monosakarida dan disakarida kecuali sukrosa berperan sebagai agensia pereduksi dan karenanya dikenal sebagai gula reduksi. Maka, sebanyak $2124 \mathrm{mg} / \mathrm{L}$ diindikasikan sebagai gula reduksi hasil hidrolisis (pemecahan gula).

Tabel 1. Hasil analisis gula total dari proses hidrolisis menggunakan metode Dubois.

\begin{tabular}{|c|l|c|}
\hline No. & Pengukuran & Hasil (mg/L) \\
\hline 1. & Xilan $\mathrm{HCl}(\mathrm{XI})$ & 2906 \\
\hline 2. & Kontrol (-) xilan & 782 \\
\hline
\end{tabular}

Berdasarkan Tabel 1, dijelaskan bahwa sebanyak 2906 mg/L merupakan hasil dari total pemecahan gula atau hidrolisis.

Apabila dibandingkan dengan penelitian Hayuningtyas et al., (2014), polisakarida jerami hasil pretreatmen yang telah dilakukan hidrolisis asam menggunakan $\mathrm{H}_{2} \mathrm{SO}_{4}$ selama 1 jam pada suhu $120^{\circ} \mathrm{C}$ tekanan 1 atm menghasilkan gula reduksi $21,7 \mathrm{~g} / 100 \mathrm{~g}$ serbuk jerami padi. Berdasarkan penelitian tersebut jika dibandingkan, maka memiliki hasil yang lebih besar dalam perolehan gula reduksi. Mengingat pada penelitian Hayuningtyas et al., (2014) tersebut menggunakan $\mathrm{NaOH}$ sebagai pengekstrak dalam proses pretreatmen, maka yield yang dihasilkan sama yakni berupa gula xilan. Sedangkan hidrolisis jerami padi tanpa penambahan asam (kontrol) selama 1 jam pada suhu $120^{\circ} \mathrm{C}$ tekanan 1 atm menghasilkan gula reduksi sebesar 5,16 $\mathrm{g} / 100 \mathrm{~g}$ serbuk jerami padi. Sama hal nya dengan perlakuan, untuk kontrol hasilnya pun lebih besar. Artinya, penggunaan asam $\mathrm{HCl}$ lebih efektif dibandingkan dengan $\mathrm{H}_{2} \mathrm{SO}_{4}$.

\section{KESIMPULAN DAN SARAN}

1. Kondisi optimum proses hidrolisis asam pada polisakarida xilan dibuktikan dari hasil optimasi jenis asam kuat terbaik yang digunakan adalah $\mathrm{HCl}$, karena memiliki efisiensi penambahan $\mathrm{Na}_{2} \mathrm{CO}_{3} 10 \%$ lebih sedikit untuk mencapai $\mathrm{pH}$ netral dibandingkan dengan $\mathrm{H}_{2} \mathrm{SO}_{4}$. Selain itu $\mathrm{HCl}$ juga dapat mendapatkan jumlah gula reduksi yang lebih banyak jika dibandingkan dengan hidrolisis menggunakan $\mathrm{H}_{2} \mathrm{SO}_{4}$.

2. Jumlah perolehan gula reduksi dari proses hidrolisis asam yang paling optimum (HCl) pada polisakarida xilan sebesar 2124 $\mathrm{mg} / \mathrm{L}$.

\section{SARAN}

Saran yang diberikan dalam laporan kemajuan penelitian ini adalah,

1. Penetralan $\mathrm{pH}$ pada proses hidrolisis oleh asam kuat sebaiknya menggunakan Natrium Hidroksida $(\mathrm{NaOH})$, bukan Natrium Karbonat $\left(\mathrm{Na}_{2} \mathrm{CO}_{3}\right)$ karena proses penetralan akan membutuhkan jumlah yang lebih banyak dibandingkan $\mathrm{NaOH}$.

2. Seharusnya dilakukan uji gula pereduksi selain uji gula total, untuk membuktikan secara semi kuantitatif hasil gula yang telah tereduksi atau terhidrolisis.

3. Perlu dilakukan uji kuantitatif yakni HPLC (High Performance Liquid Chromatography) untuk mengetaui jenis gula hasil hidrolisis atau gula pereduksi. 


\section{UCAPAN TERIMA KASIH}

Ucapan terima kasih kami sampaikan kepada DRPM DIKTI yang telah mendanai penelitian ini. Ucapan terima kasih pula tidak lupa kami sampaikan kepada PT. Angler Biochemlab dalam membantu analisis gula total.

\section{DAFTAR PUSTAKA}

Aniriani, G.W., A. Meryandini dan Yopi. 2014. Hidrolisis Xilan Bagas Menggunakan Xilanase Bacillus subtilis 28 dan Karakterisasi Enzimnya. Jurnal Biologi Indonesia. 11(1): 1-9.

Delmer, D.P. and C.H. Haigler. 2002. The regulation of metabolic flux to cellulose, a major sink for carbon in plants. Metab. Eng. 4:22-28.

Dubois, M., K.A. Gilles, J.K. Hamilton, P.A. Rebers and F. Smith. 1956. Colorimetric method for determination of sugars and related substances. Division of Biochemistry, University of Minnesota, St. Paul, Min. Vol.28, no. 3 .

Feller, R.L., S.B. Lee and J. Bogaard. 1986. The kinetic of cellulose deterioration. Advances in Chemistry, ACS series. 212:329-347.

Gray, K.A.,L. Zhao and M. Emptage. 2006. Bioethanol. Elsivier (Curent Opinion in Chemical Biology). 10: 141-146.

Hayuningtyas, S.K. et al. 2014. Produksi Bioetanol dari Jerami (Oryza sativa) melalui Hidrolisis Asam dan Fermentasi dengan Saccharomyces cereviceae. Bioteknologi 11 (1): 1-4. ISSN: 0216-6887, EISSN: 2301-8658, DOI: 10.13057.

Harry, W.L. and J.M. Christoper. 1989. Experimental Organic Chemistry: Principles and Practice. Wiley Blackwell. Pp. 159 - 173. ISBN 978-0632-02017-1.

Iranmahboob, J., F. Nadim and S. Monemi. 2002. Optimizing acid-hydrlysis: a critical step for production of ethanol from mixed wood chips. Biomass and Bioenergy, 22: $401-404$.
Lavarack, B.P., G.J. Griffin and D. Rodman. 2002. The acid hydrolysis of sugarcane bagas hemicellulose to produce xylose, arabinose, glucose and other products. Biomass Bioenergy.,23, 367-380.

Miller, G.L. 1959. Use of dinitrosalycilic acid reagent for determination of reducing sugar. Anal Chem (31):426-428.

Mosier, N. C. Wyman, B. Dale, R. Elander, Y.Y. Lee, M. Holtzapple and M. Ladisch. 2005. Features of promising technologies for pretreatment of lignocellulosic biomass. Bioresource Technol., 96, 673-686.

Prakash, P., S.K. Jayalaksmi and B. Prakash. 2012. Production of alkaliphilic, halotolerent, thermostable cellulosefree xylanase by Bacillus halodurans PPKS-2 using agro waste:single step purification and characterization. World J Microbiol Biotechnol (2012) 28:183-192.

Reginaldo, dkk. 2007. Structure, organization, and functions of cellulose synthase complexes in higher plants. Biotechnology Researcher Center, USA.

Riyanti, E.I. 2008. Biomassa sebagai bahan baku bioethanol. Jurnal Litbang Pertanian, 28(3).

Sun, Y., and J. Cheng. 2002. Hydrolysis of lignocellulosic materials for ethanol production: a review. Bioresource Technol., 83, 1-11.

Taherzadeh, M.J. and K. Karimi. 2007. Enzymes-based hydrolysis processes for ethanol from lignocellulosic materials: a review. Bioresources 2(4), 707-738.

Vogel, A.R., B.S. Tatchell, A.J. Hannaford, and P.W.G. Smith. Vogel's Textbook of Practical Organic Chemistry. 2013. ISBN 0-582-46236-3. 